\title{
Interactive effects of global and regional change on a coastal ecosystem
}

\author{
Karsten Reise · Justus E. E. van Beusekom
}

Received: 27 September 2007 / Revised: 7 December 2007 / Accepted: 14 December 2007 / Published online: 11 January 2008 (C) Springer-Verlag and AWI 2008

\begin{abstract}
Shallow waters and lowland meet at the same level in the Wadden Sea, but are separated by walls of coastal defense. What are the prospects of this coastal ecosystem in a warmer world? We focus on tidal waters and inshore sedimentary bottoms, expect nutrient supply from land to decline and species introductions, temperature and sea level to rise. The effects are interrelated and will have an increasing likelihood of abrupt and irreversible developments. The biotic interactions are hardly predictable but we anticipate the following changes to be more likely than others: blooms of phytoplankton will be weak mainly because of increasing pelagic and benthic grazing pressure, both facilitated by warming. Possibly birds feeding on mollusks will encounter decreasing resource availability while fisheaters benefit. Extensive reefs of Pacific oysters could facilitate aquatic macrophytes. Sea level rise and concomitant hydrodynamics above tidal flats favor well-anchored suspension feeders as well as burrowing fauna adapted to dynamic permeable sand. With high shares of immigrants from overseas and the south, species richness will increase; yet the ecosystem stability may become lower. We suggest that for the next decades invasions of introduced species followed by warming and declining nutrient supply will be the most pressing factor on the changes in the Wadden Sea ecosystem, and the effects of sea level rise to be the key issue on the scale of the whole century and beyond.
\end{abstract}

Keywords Introduced species - Global warming - Sea level rise $\cdot$ Nutrients $\cdot$ Benthos $\cdot$ Plankton · Wadden Sea

Communicated by J. van Beusekom.

K. Reise $(\bowtie) \cdot$ J. E. E. van Beusekom

Alfred Wegener Institute for Polar and Marine Research, Wadden Sea Station Sylt, Hafenstrasse 43, 25992 List, Germany e-mail: Karsten.Reise@awi.de

\section{Introduction}

Coastal regions at equal level with the sea will need precautious adaptations against effects of global change. Such coastal management needs knowledge on prospective ecosystem developments. We here consider strong interactions among (1) a swelling tide of species introductions, (2) global warming, (3) storm frequencies and sea level rise, and (4) declining nutrient over-supplies to identify major causal pathways. The focus is on the northern Wadden Sea. This is a coastal region of outstanding natural beauty: behind a barrier of high sands and dunes, vast intertidal flats with scattered islets are intersected by deep channels. Since medieval times, the tidal area grew larger at the expense of low-lying marshes until coastal defense and land reclamation struck back (Reise 2005). Since then the tidal area is increasingly squeezed into a corset of defended shorelines.

Patterns of past changes in the Wadden Sea ecosystem have been caused by the overexploiting of oysters, fish, birds and marine mammals (Lotze et al. 2005). Recent reversals occurred in birds and seals because of protection. The effects of nutrient over-supply on algae and consumers have been moderate compared to the more enclosed seas such as the Baltic. Wetlands and natural shorelines have vanished behind armored defense structures against flooding and erosion. This change is similar to other coasts in Europe (Airoldi and Beck 2007) and the temperate world (Lotze et al. 2006; Valiela 2006). The effects of the past drivers will linger on and interact with the effects of contemporary global and regional change. Declining nutrient over-supplies may curtail potential blooms of primary producers, and species introductions, global warming and sea level rise will impose the most important changes. We emphasize that all pressures on the ecosystem have to be considered in concert because of their interacting effects (Didham et al. 2007). 
At the scale of decades, the North Sea has undergone regime shifts triggered by climate fluctuations (Weijerman et al. 2005) and the occasional occurrence of severe continental winters had strong intermittent effects on benthic (Beukema and Dekker 2005; Strasser et al. 2003) and pelagic biota (Martens and van Beusekom 2008). Summer temperatures in the last decade have already exceeded those previously measured (van Aken 2003; Wiltshire and Manly 2004) and the probability of having another severe winter is $<10 \%$ (MacKenzie and Schiedek 2007). Decadal variations may continue to confound anthropogenic trends. We venture to speculate on trends beyond a few decades because this is the scale where the human impact is expected to exceed natural variability.

\section{Pelagic interactions in less eutrophic but warmer coastal waters}

The shallow water ecosystem of the Wadden Sea is fueled by coastward accumulation of phytoplankton and organic and inorganic matter from North Sea coastal waters (Verwey 1952; Postma 1954). With decreasing riverine nutrient loads, off-shore primary production will decrease, the supply of organic and inorganic matter from the North Sea will become smaller (van Beusekom and de Jonge 2002) and clearer water in the Wadden Sea may promote benthic primary producers and strengthen the benthic food web at the expense of the pelagic food web (van Beusekom 2005; Loebl et al. 2008; van Beusekom et al. 2008). Herbivorous zooplankton will benefit from higher temperatures over a longer season and will thus exert more grazing pressure on the phytoplankton (Fig. 1; Martens and van Beusekom 2008). Also, we expect higher benthic filtration rates at higher ambient temperatures. The combined effect of pelagic and benthic grazing may suppress the magnitude of phytoplankton spring bloom (Keller et al. 1999). This conjecture may be oversimplified. Carnivores in the zooplankton like Oithona similis will also benefit from higher temperatures (Martens and van Beusekom 2008) and release grazing pressure on the phytoplankton. The recently introduced American ctenophore Mnemiopsis leydi has the potential to prey heavily on all zooplankton (Boersma et al. 2007). The same applies to warm-water pelagic fish immigrating from the south (see below). This may lower pelagic top-down control on phytoplankton but still there is a synergism of warming with an overall declining nutrient supply which leads us to conclude that in the future phytoplankton blooms will decrease rather than increase (Fig. 1). However, with several components of top-down control under change, the contribution of phytoplankton to the Wadden Sea ecosystem is liable to rapid compositional and quantitative shifts with high fluctuations between years.
Global policy
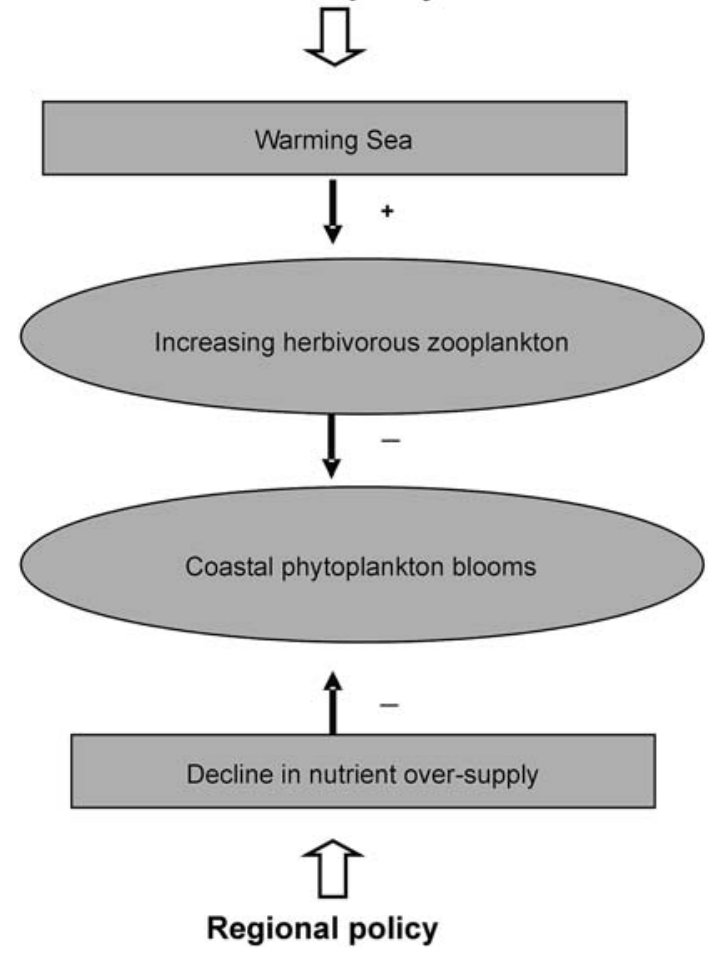

Fig. 1 Synergism of global and regional drivers suppressing blooms of coastal phytoplankton

This will be a challenge to benthic suspension feeders in the Wadden Sea.

\section{Species introductions, warming and the increasing role of benthic suspension feeders}

The Wadden Sea is receiving an increasing amount of species introduced from overseas by means of shipping and intentional introductions (Fig. 2) with cascading effects on the ecosystem (i.e., Reise et al. 1999, 2005; Buschbaum et al. 2006;

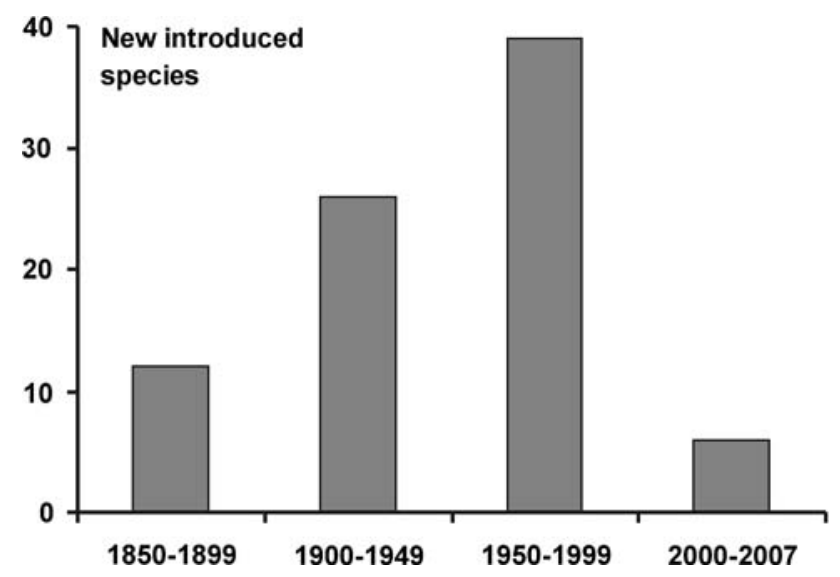

Fig. 2 Timeline of species introductions into the North Sea with a recent rate of 1 taxon year ${ }^{-1}$ 
Nehls et al. 2006). This fate is shared with many other coastal regions (i.e., Maron et al. 2006; Pranovi et al. 2006; Ruesink et al. 2006). Although there are intentions to reduce the flux of introduced species with ballast water treatment, we suspect that this will be obfuscated by a proliferating global trade. With an expected retreat of Arctic ice, vessels from the Pacific will be no more size-limited by narrow passages and sail straight into the North Sea. This new shipping route most likely will bring about an unprecedented wave of Pacific immigrants, many of which are likely to exhibit boom and bust dynamics after the initial introduction (Reise et al. 2006).

Global warming has been shown to trigger invasions in the Wadden Sea because almost all introduced species originate from warmer coasts than those of the North Sea. There is a strong synergism between two aspects of global economy, the increasing greenhouse gas emissions and trade across the oceans. At the upper shore, the cordgrass Spartina anglica first introduced in the 1920s, only recently seems to realize its full ecological potential with an earlier warming in spring (Loebl et al. 2006). When Pacific oysters Crassostrea gigas have been introduced for cultivation in the northern Wadden Sea, it was assumed that they could not recruit at the prevailing low temperatures. However, recent warming greatly facilitated recruitment and large reefs have been formed (Diederich et al. 2005). Another introduced suspension feeder, the American slipper limpet Crepidula fornicata, was limited in the Wadden Sea by severe winters (Thieltges et al. 2004). However, the last harsh winter occurred already more than 10 years ago and since then the population attained unprecedented densities. The three invaders referred to above, show positive feedbacks from one generation to the next by providing suitable settling conditions for their recruits. This accelerates invasions following prolonged lag phases after initial introduction.

Also introduced ascidians, i.e., Molgula manhattensis and Styela clava, became abundant and further add to the guild of suspension feeders, most of which established just above and below the low tide level. In addition to the introduced epibenthic suspension feeders, the infaunal American razor clam Ensis (directus) americanus, first introduced in the late 1970s, quickly has advanced to become a dominant suspension feeder in the shallow subtidal zone and probably equals the stocks of native intertidal cockles and mussels in biomass (Armonies and Reise 1999) and dominates the bivalve larval plankton (Strasser and Günther 2001). Shells protruding out of the sediment often serve as the substrate for oysters, slipper limpets and ascidians.

Contrary to this gain in introduced suspension feeders, populations of native bivalves have declined independently (Beukema and Dekker 2005; Nehls et al. 2006). The underlying process is assumed to be strong predation pressure by shrimp and shore crabs on bivalve spat. Severe winters are needed for temporal mismatch in this predator-prey inter- action. However, the chance for this to happen has become low (Beukema 1992; see also MacKenzie and Schiedek 2007). A decline in clams already seems to affect birds preying on mollusks (Blew and Südbeck 2005). The so-far introduced species are no substitute because of strong shells or their main occurrence being subtidal and thus out of reach for wading birds. Global warming apparently has reversed effects on resident and introduced benthic suspension feeders (Fig. 3) with cascading effects through the food web.

More alien suspension feeders will be introduced and also new predators may arrive (i.e., Kerckhof et al. 2006; Corkum et al. 2004). Similarly, diseases are likely to spread under warmer conditions. At the Atlantic coast of France, the so-called summer disease is causing mortality in $C$. gigas (Samain et al. 2004) and also seems to affect the population in the southern Wadden Sea (N. Dankers and M. Herlyn, personal communication). The effects of native parasites on introduced bivalves are low (Krakau et al. 2006), and new arrivals among parasites are few (Thieltges et al. 2008). Thus, the introduced suspension feeders still proliferate, but there is no evidence that they competitively exclude the residents on a regional scale and the interactions are often ambivalent (Diederich 2005; Thieltges et al. 2006). The interesting question, whether exploitation competition between introduced and native suspension feeders will play a significant role arises, particularly in view of declining phytoplankton blooms (Fig. 1). Invasions of neobiota often become rapid or abrupt and essentially constitute an irreversible change in ecosystem composition and functioning. Numerically this process brings about an increase in species richness.

\section{Invasive benthic ecosystem engineers}

Biogenic habitat modifications in coastal sediments are at least as important as food web interactions for ecosystem functioning (Reise 2002). Reefs of Pacific oysters will replace resident mussel beds of the Wadden Sea with moderate effects on associated species (Büttger et al. 2008). However, oysters may accumulate more shell mass by rapid

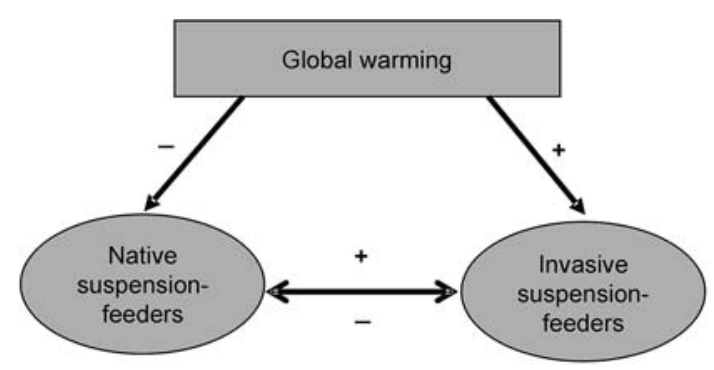

Fig. 3 Global warming facilitating invader dominance and inhibiting recruitment of residents. Within-guild interactions may not entail exclusion of residents (see text) 
growth to a much larger size than mussels (Fig. 4). In spite of grazing by periwinkles this additional substrate will provide attachment to resident macroalgae as well as to the invasive Gracilaria vermiculophylla in the intertidal and Sargassum muticum in the shallow subtidal zone (C. Buschbaum, own observation). Improved water clarity as a result of declining phytoplankton may be an interaction facilitating these macroalgae, and the benthic suspension feeders may exacerbate this effect even further. Such reefs with macroalgae may provide improved shelter for small fish or cuttlefish immigrating from the south. Shell beds of introduced slipper limpets and razor clams will also increase biogenic hard substrate around low tide level.

At high tide level, the recently accelerated invasion of the Spartina-grass (Loebl et al. 2006) may mitigate erosion at saltmarsh edges. Such edge erosion is expected to be a consequence of a rising high tide level at sediment deficient shorelines (see Reise et al. 2008). These would be indirect antagonistic interaction effects of global warming and the globalization of coastal vegetation. To what extent the balance may change between important native bioengineers such as the lugworm Arenicola marina maintaining mobile permeable sand (Volkenborn et al. 2007) and seagrass accumulating fine sediment particles will need research. Seagrass beds in the Wadden Sea seem to be liable to changes in storm frequency (Reise and Kohlus 2008). We suggest that the interplay of bioengineering species in the Wadden Sea will profoundly change in the coming decades with cascading effects on food web structure.

\section{Ecosystem change}

In a warmer Wadden Sea, we expect strong bentho-pelagic coupling in spring because of proliferating alien suspension

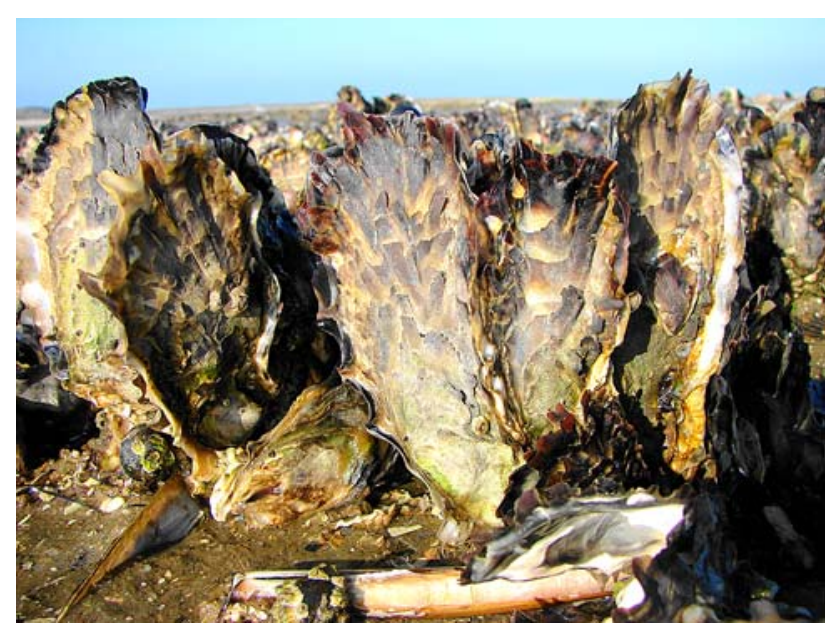

Fig. 4 Accumulating shell mass by invasive Crassostrea gigas and Ensis americanus in the northern Wadden Sea, October 2007 feeders. In the summer, pelagic grazers take over (M. Loebl and J. E. E. van Beusekom, submitted data). Both processes would improve water clarity facilitating benthic vegetation. With declining nutrient concentrations blooms of Phaeocystis globosa and massive developments of benthic green algal mats may phase out. Whether large flocks of migrant birds breeding in the rapidly warming Arctic region will continue to abound in the Wadden Sea is unknown. More species of fish will immigrate in response to warmer waters than resident species retreat (Hiscock et al. 2004). The first to arrive from adjacent warmer waters are small pelagic fish. Fish-eating birds like terns and cormorants may benefit from this development. Some fish, like cold-water eelpout Zoarces viviparus and cod Gadus morrhua, are likely to retreat northward (Beaugrand et al. 2003; Perry et al. 2005; Pörtner and Knust 2007).

Benthic invertebrates will be slower to immigrate (Hiscock et al. 2004). Most coastal species of the East Atlantic have wide latitudinal ranges (see De Vooys 1990) and hence not much change in species composition is expected for the Wadden Sea but relative abundances may differ in many cases (i.e., Beukema 1992; Beukema and Dekker 2005; Kirby et al. 2007; Philippart et al. 2003). Abrupt effects are to be expected from invasions by alien species facilitated by warmer conditions (see above). These will continue to shift the benthos on an irreversible trajectory with ever new structural and functional configurations. From there the causal pathways will continue to impact pelagic and sedimentary components of the coastal ecosystem.

In the long run, the overriding pressure will inevitably be an accelerating rise in high tide level. According to Rahmstorf (2007) mean global sea level rise until 2100 may be in the order of $1 \mathrm{~m}$ with a wide range of uncertainty. However, this uncertainty refers to the rate of increase and not to the final magnitude. During the last interglacial with peak temperatures of $2-4^{\circ} \mathrm{C}$ higher than present, the sea level was roughly $4-6 \mathrm{~m}$ higher than it is now (IPCC 2007). Seawalls could be built high enough, but the tidal ecosystem would be subject to much stronger hydrodynamics when coastal accretion is not keeping pace with sea level rise. This would be beneficial to suspension feeders well anchored at the bottom. The introduced Pacific oysters fulfill this requirement and even provide anchorage and shelter to others. Also, deep burrowing or highly mobile organisms would be able to cope with unstable sediments (Lackschewitz and Reise 1998). Conversely, epipelic diatoms and hydrobiid snails grazing upon them are hypothesized to be potential losers together with the feeble intertidal seagrasses. This is supported by a significant long-term depletion of mud caused by the prevailing hydrodynamics (Dolch and Hass 2008).

Saltmarshes will shrink, mud flats will give way to sand flats and all these, further to subtidal bottoms. The net effect 
will be a loss in habitat diversity. To what extent the natural rates of sediment deposition are sufficient to keep up with sea level rise will vary between tidal basins (CPSL 2005). Large tidal basins with narrow inlets are expected to turn into lagoons first. There, saltmarshes will erode at the edges and tidal flats will become permanently submerged. Wading birds foraging on tidal flat benthos will run out of feeding ground. The shortage of sediment will eventually also affect the barrier islands, which are vital for tourism and thus for regional economy. Therefore, we suspect that large-scale sand replenishments will be undertaken to compensate the arising sediment deficiencies. Such a sediment management may mitigate to some extent the loss of intertidal habitats.

\section{Outlook and conclusions}

We assume that future policies will aim for sustainability including the protection of the unique natural values of the Wadden Sea. With species introductions, global warming, sea level rise and a reversal in nutrient over-supply, we made a subjective selection of interacting processes likely to be more important for ecosystem change than the other impacts. Nevertheless, some of them should be mentioned: according to the Trilateral Wadden Sea Plan (Stade Declaration 1997) enhanced use of resources is not to be expected. To what extent future 'sea ranching' will affect the Wadden Sea ecosystem is not foreseeable. Potential reintroductions of lost species probably will not change the ecosystem more than other immigrants do it anyway. Pollution with harmful substances including novel ones and those released by accidents may not exceed the contemporary levels. Warming may not only facilitate biotic invasions but also those of tourists. This will entail further infrastructural and residential developments in the region. Sea level rise entails higher and stronger seawalls and more sand replenishments. Finally, further precautionary adjustments to sea level rise will become necessary. However, this is a contentious issue and the respective societal decisions cannot be foreseen. Taken together, these reflections on other aspects than the ones we have considered are either not likely to alter the overall picture or are not predictable.

We conclude that an ongoing tide of species introductions will continue to cause abrupt and profound irreversible changes in the Wadden Sea ecosystem. Superimposed are immigrations of warm-water fish, while only few coldwater species are expected to be lost from the Wadden Sea. The net result is an increase in species richness. A strong guild of benthic suspension feeders, intense pelagic grazing and fewer nutrients may improve water clarity. The loss of mud as a corollary of sea level rise may also contribute to more transparency. A dominant habitat structure at the low intertidal zone will be reefs of Pacific oysters with facilitating effects on dermersal plants. Rising high tide levels with more turbulent waters will challenge biogenic structures and only the most resistant to hydrodynamic stress may persist. These considerations should help to disentangle annual and decadal variations from anthropogenic longterm changes which tend to be masked by high short-term variability. Our suggestions may also serve as hypotheses to be challenged with more detailed reconstructions of the past developments and refined observations in the future, considering interactive effects, which may either mitigate or exacerbate the total net ecosystem effects.

While coastal regions should particularly contribute to the mitigation efforts to reduce further anthropogenic climate changes, coastal management needs to pursue measures of precautionary adaptations. Faced with an unprecedented rate of warming, further reductions of nutrient release into the sea are advisable to avoid algal mass developments, oxygen deficiencies and diseases. To accommodate and integrate the swelling tide of invaders, coastal habitat diversity and habitat connectivity will need to be restored at the land-sea and fresh-marine water transitions. This requires ambitious programs of habitat restorations and adaptations to enhanced sea level rise (Reise 2003). With a fixed line of coastal defense, innovative means of adapting the Wadden Sea to accelerating sea level rise are probably the greatest challenge. Otherwise the Wadden Sea tidal areas will eventually turn into lagoons with a corset of stone-walled defenses, and without its extensive tidal zone of sedimentary flats fringed by its salt marshes, the Wadden Sea ecosystem would lose its most characteristic natural feature and uniqueness.

Acknowledgments We thank all participants of the workshop on Long-term change in the northern Wadden Sea, February 2007, for lively discussions which have fueled this review on the prospects of the Wadden Sea ecosystem. Werner Armonies is thanked for critical suggestions on the manuscript. The authors acknowledge the support by the MARBEF network of excellence "Marine Biodiversity and Ecosystem Functioning" which is funded in the Community's Sixth Framework Programme (contract no. GOCE-CT-2003-505446).

\section{References}

Airoldi L, Beck MW (2007) Loss, status and trends for coastal marine habitats of Europe. Oceanogr Mar Biol Ann Rev 45:345-405

Armonies W, Reise K (1999) On the population development of the introduced razor clam Ensis americanus near the island of Sylt (North Sea). Helgol Meeresunters 52:291-300

Beaugrand G, Brander KM, Lindley JA, Soussi S, Reid PC (2003) Plankton effect on cod recruitment in the North Sea. Nature 426:661-664

Beukema JJ (1992) Expected changes in the Wadden Sea benthos in a warmer world: lessons from periods with mild winters. Neth J Sea Res 30:73-79 
Beukema JJ, Dekker R (2005) Decline of recruitment success in cockles and other bivalves in the Wadden Sea: possible role of climate change, predation on postlarvae and fisheries. Mar Ecol Prog Ser 287:149-167

Blew J, Südbeck P (eds) (2005) Migratoty water birds in the Wadden Sea 1980-2000. Wadden Sea Ecosystem 20. Common Waden Sea Secretariat, Wilhelmshaven

Boersma M, Malzahn AM, Greve W, Javidpour J (2007) The first occurrence of the ctenophore Mnemiopsis leidyi in the North Sea. Helgol Mar Res 61:153-155

Buschbaum C, Chapman AS, Saier B (2006) How an introduced seaweed can affect epibiota diversity in different coastal systems. Mar Biol 148:743-754

Büttger H, Asmus H, Asmus R, Buschbaum C, Dittmann S, Nehls G (2008) Community dynamics of intertidal soft-bottom mussel beds over two decades. Helgol Mar Res 62. doi:10.1007/s10152007-0099-y

Corkum LD, Sapota MR, Skora KE (2004) The round goby, Neogobius melanostomus, a fish invader on both sides of the Atlantic Ocean. Biol Invasions 6:173-181

CPSL (2005) Coastal protection and sea level rise. Solutions for sustainable coastal protection in the Wadden Sea region. Wadden Sea Ecosystem 21. Common Wadden Sea Secretariat, Wilhelmshaven, Germany

De Vooys CGN (1990) Expected biological effects of long-term changes in temperature on benthic ecosystems in coastal waters around The Netherlands. In: Beukema JJ, Wolff WJ, Brouns JJWM (eds) Expected effects of climate change on marine coastal ecosystems. Dev Hydrobiol 57:77-82

Didham RK, Tylianakis JM, Gemmell NJ, Rand TA, Ewers RM (2007) Interactive effects of habitat modification and species invasion on native species decline. Trends Ecol Evol 22:489-496

Diederich S (2005) Differential recruitment of introduced Pacific oysters and native mussels at the North Sea coast: coexistence possible? J Sea Res 53:269-281

Diederich S, Nehls G, van Beusekom JEE, Reise K (2005) Introduced Pacific oysters (Crassostrea gigas) in the northern Wadden Sea: invasion accelerated by warm summers? Helgol Mar Res 59:97106

Dolch T, Hass HC (2008): Long-term changes of intertidal and subtidal sediment compositions in a tidal basin in the Northern Wadden Sea (SE North Sea) Helg Mar Res 62. doi:10.1007/s10152-0070090-7

Hiscock K, Southward A, Tittley I, Hawkins S (2004) Effects of changing temperature on benthic marine life in Britain and Ireland. Aquatic Conserv: Mar Freshw Ecosyst 14:333-362

IPCC (2007) Summary for policy makers. In: Climate Change, The physical science basis. Solomon et al. (eds) Cambridge Univ Press, Cambridge

Kerckhof F, Vink RJ, Niewig DC, Post JNJ (2006) The veined whelk Rapana venosa has reached the North Sea. Aquat Invasions 1:3537

Keller AA, Oviatt CA, Walker HA, Hawk JD (1999) Predicted impacts of elevated temperature on the magnitude of the winter-spring phytoplankton bloom in temperate coastal waters: A mesocosm study. Limnol Oceanogr 44:344-356

Kirby RR, Beaugrand G, Lindley JA, Richardson AJ, Edwards M, Reis PC (2007) Climate effects and benthic-pelagic coupling in the North Sea. Mar Ecol Prog Ser 330:31-38

Krakau M, Thieltges DW, Reise K (2006) Parasites in introduced bivalves-implications for a coastal ecosystem. Biol Invasions 8:919-925

Lackschewitz D, Reise K (1998) Macrofauna on flood delta shoals in the Waden Sea with an underground association between the lugworm Arenicola marina and the amphipod Urothoe poseidonis. Helgoländer Meeresunters 52:147-158
Loebl M, Colijn F, Martens P, van Beusekom JEE (2008) Long-erm phytoplankton dynamics in the northern Wadden Sea. Helgol Mar Res 62. doi:10.1007/s10152-007-0089-0

Loebl M, van Beusekom JEE, Reise K (2006) Is spread of the neophyte Spartina anglica recently enhanced by increasing temperatures? Aquat Ecol 40:315-324

Lotze HK, Lenihan HS, Bourque BJ, Bradbury RH, Cooke RG, Kay SM, Kidwell SM, Kirby MX, Peterson CH, Jackson JB (2006) Depletion, degradation, and recovery potential of estuaries and coastal seas. Science 312:1806-1809

Lotze KH, Reise K, Worm B, van Beusekom J, Busch M, Ehlers A, Heinrich D, Hoffmann RC, Holm P, Jensen C, Knottnerus OS, Langhanki N, Prummel W, Vollmer M, Wolff WJ (2005) Human transformations of the Wadden Sea ecosystem through time: a synthesis. Helgol Mar Res 59:84-95

MacKenzie BR, Schiedek D (2007) Daily ocean monitoring since the 1860 s shows record warming of northern European seas. Glob Change Biol 13:1335-1347

Maron JL, Estes JA, Croll DA, Danner EM, Elmendrof SC, Buckelew SL (2006) An introduced predator alters Aleutian island plant communities by thwarting nutrient subsidies. Ecol Monogr 76:324

Martens P, van Beusekom JEE (2008) Zooplankton response to a warmer northern Wadden Sea. Helg Mar Res 62. doi:10.1007/ s10152-007-0097-0

Nehls G, Diederich S, Thieltges D, Strasser M (2006) Wadden Sea mussel beds invaded by oysters and slipper limpets: competition or climate control? Helgol Mar Res 60:135-143

Perry AL, Low PJ, Ellis JR, Reynolds JD (2005) Climate change and distribution shifts in marine fishes. Science 308:1912-1915

Philippart CJM, Van Aken HM, Beukema JJ, Bos OG, Cadée GC, Dekker R (2003) Climate-related changes in recruitment of the bivalve Macoma balthica. Limnol Oceanogr 48:2171-2185

Pörtner HO, Knust R (2007) Climate change affects marine fishes through the oxygen limitation of thermal tolerance. Science 315:95-97

Postma H (1954) Hydrography of the Dutch Wadden Sea. Arch néerlandaises de Zool 10:405-511

Pranovi F, Franceschini G, Casale M, Zuccheta M, Torricelli P, Giovanardi $\mathrm{O}$ (2006) An ecological imbalance induced by a non-native species: the Manila clam in the Venice lagoon. Biol Invasions 8:595-609

Rahmstorf S (2007) A semi-empirical approach to projecting future sea-level rise. Science 315:368-370

Reise K (2002) Sediment mediated species interactions in coastal waters. J Sea Res 48:127-141

Reise K (2003) More sand to the shorelines of the Wadden Sea. Harmonizing coastal defense with habitat dynamics. In: Wefer G, Lamy F, Mantoura F (eds) Marine science frontiers for Europe. Springer-Verlag, Berlin Heidelberg New York Tokyo, pp 203216

Reise K (2005) Coast of change: habitat loss and transformations in the Wadden Sea. Helgol Mar Res 59:9-21

Reise K, Gollasch S, Wolff WJ (1999) Introduced marine species of the North Sea coasts. Helgol Meeresunters 52:219-234

Reise K, Dankers N, Essin K (2005) Introduced species. In: Wadden Sea Quality Status Report 2004. Waden Sea Ecosystem 19. Common Wadden Sea Secretariat, Wilhelmshaven, Germany, pp 155161

Reise K, Olenin S, Thieltges DW (2006) Are aliens threatening European aquatic coastal ecosystems? Helgol Mar Res 60:77-83

Reise K, Herre E, Sturm M (2008) Mudflat biota since the 1930s: change beyond return? Helgol Mar Res 62. doi:10.1007/s10152007-0087-2

Reise K, Kohlus J (2008) Seagrass recovery in the Northern Wadden Sea? Helgol Mar Res 62. doi:10.1007/s10152-007-0088-1 
Ruesink JL, Feist BE, Harvey CJ, Hong JS, Trimble AC, Wisehart LM (2006) Changes in productivity associated with four introduced species: ecosystem transformation of a 'pristine' estuary. Mar Ecol Prog Ser 311:203-215

Samain JF et al (17 authors) (2004) Summer mortality in the Pacific oysters Crassostrea gigas, overview of three years of results of the cooperative "Morest" project. J Shellfish Res 23:309-310

Stade declaration (1997) Common Wadden Sea Secretariat, Wilhelmshaven, Germany

Strasser M, Dekker R, Essink K, Günther CP, et al. (2003) How predictable is high bivalve recruitment in the Wadden Sea after a severe winter? J Sea Res 49:47-57

Strasser M, Günther C-P (2001) Larval supply of predator and prey: temporal mismatch between crabs and bivalves after a severe winter in the Wadden Sea. J Sea Res 46:57-67

Thieltges DW, Strasser M, van Beusekom JEE, Reise K (2004) Too cold to prosper-winter mortality prevents population increase of the introduced American slipper limpet Crepidula fornicate in northern Europe. J Exp Mar Biol Ecol 311:375-391

Thieltges DW, Strasser M, Reise K (2006) How bad are invaders in coastal waters? The case of the American slipper limpet Crepidula fornicata in western Europe. Biol Invasions 8:1673-1680

Thieltges DW, Hussel B, Hermann J, Jensen KT, Krakau M, Taraschewski H, Reise K (2008) Parasites in the northern Wadden Sea: a conservative ecosystem component over 4 decades. Helgol Mar Res 62. doi:10.1007/s10152-007-0091-6
Valiela I (2006) Global coastal change. Blackwell Publ, Oxford, UK

Van Aken HM (2003) 140 years of daily observations in a tidal inlet (Marsdiep). ICES Mar Sci Symp 219:359-361

van Beusekom JEE (2005) A historic perspective on Wadden Sea eutrophication. Helgoland Mar Res 59:45-54

van Beusekom JEE, Weigelt-Krenz S, Martens P (2008) Long-term variability of winter nitrate concentrations in the northern Wadden Sea driven by freshwater discharge, decreasing riverine loads and denitrification. Helgol Mar Res 62. doi:10.1007/s10152-0070092-5

van Beusekom JEE, de Jonge VN (2002) Long-term changes in Wadden Sea nutrient cycles: importance of organic matter import from the North Sea. Hydrobiologia 475/476:185-194

Verwey J (1952) On the ecology of cockle and mussel in the Dutch Wadden Sea. Archs néerl Zool 10:171-239

Volkenborn N, Hedtkamp SIC, van Beusekom JEE, Reise K (2007) Effects of bioturbation by lugworms (Arenicola marina) on physical and chemical sediment properties and implications for intertidal habitat succession. Estuarine Coast Shelf Sci 74:331-343

Weijerman M, Lindeboom H, Zuur AF (2005) Regime shifts in marine ecosystems of the North Sea and Wadden Sea. Mar Ecol Prog Ser 298:21-39

Wiltshire KH, Manly BFJ (2004) The warming trend at Helgoland Roads, North Sea: phytoplankton response. Helgol Mar Res 58:269-273 